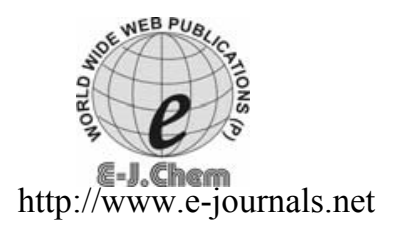

ISSN: 0973-4945; CODEN ECJHAO

E-Journal of Chemistry

2012, 9(1), 43-48

\title{
Synthesis and Low Temperature Crystal Structure of Disodium Tetrapotasium Decavanadate
}

\author{
M. R. MOHAMMADI and M. HAKIMI* \\ Department of Chemistry \\ Payame Noor University (PNU), 1939-4697, Tehran, I.R of Iran \\ mrmohamadi@yahoo.com
}

Received 21 March 2011; Accepted 30 April 2011

\begin{abstract}
A decavanadate $\mathrm{K}_{4} \mathrm{Na}_{2} \mathrm{~V}_{10} \mathrm{O}_{28} \cdot 10 \mathrm{H}_{2} \mathrm{O}$ has been prepared and chractrisized by, IR and Raman spectroscopy. Single crystal $\mathrm{x}$-ray analysis has been carried out on $\mathrm{H}_{20} \mathrm{~K}_{4} \mathrm{Na}_{2} \mathrm{O}_{38} \mathrm{~V}_{10}$ which crystallizes in the triclinic. System, space group $\mathrm{P}-1$, with $\mathrm{a}=8.5584(5) \AA, \mathrm{b}=10.3041(6), \mathrm{c}=10.9801(7)$ and $\mathrm{Z}=1$. Structural units $\left(\mathrm{V}_{10} \mathrm{O}_{28}{ }^{6-}\right)$ link by the interstitial contents $\left(\left[\mathrm{K}_{4} \mathrm{Na}_{2}\left(\mathrm{H}_{2} \mathrm{O}\right)_{20}\right]^{6+}\right)$.
\end{abstract}

Keywords: Polyoxometalate, Decavanadate, Single crystal, IR and Raman spectroscopy

\section{Introduction}

Polyoxometalates (POMs) are interesting nanosized inorganic clusters that have attracted much attention in recent years due to their functional properties and practiced applications in catalysis, medicine, surfaces sciences and pharmacology, ${ }^{1,2}$. Among these compounds, polyoxovanadates are especially attractive since vanadium is important for biological metabolism (trace element) ${ }^{3}$ and plays as essential role in some enzymatic activities ${ }^{4}$. Interest in synthetic and natural vanadium oxide compounds has recently been rekindled, in part because of their potential use as secondary-cathode materials for advanced Li batteries ${ }^{5}$ and their key role in oxidative catalysis ${ }^{6-8}$. Vanadium in its higher oxidation states $\left(\mathrm{V}^{\mathrm{V}}, \mathrm{V}^{\mathrm{IV}}\right)$ gives a large number of isopolyvanadates that exhibit a wide range of structures, ranging from chain metananadates $\left[\mathrm{VO}_{3}{ }^{-}\right]_{\mathrm{n}}$, to layered oxides $\left[\mathrm{V}_{2} \mathrm{O}_{5}\right]$, compact polyanion $\left[\mathrm{V}_{10} \mathrm{O}_{28}\right]^{6-}$ and polyanionic hollow cage such as $\left[\mathrm{V}_{15} \mathrm{O}_{36}\right]_{5-9}$. Decavanadate is formally a $\left[\mathrm{V}_{10} \mathrm{O}_{28}\right]^{6-}$ polyanion, four $\mathrm{K}^{+}$and two $\mathrm{Na}^{+}$cations and aqua ligands. In the present work, the results derived from low temperature single crystal diffraction data at medium resolution and Infrared and Raman spectra are reported.

\section{Experimental}

All reagents for synthesis were purchased and used without purifications. Infrared spectrum was recorded as KBr pellet on a Shimadzu FT IR - 8400 spectrometer. Raman spectrum was recorded on a Nicolet FT Raman spectrometer in a capillary tube. 


\section{Synthesis $\mathrm{K}_{4} \mathrm{Na}_{2} \mathrm{~V}_{10} \mathrm{O}_{28} \cdot 10 \mathrm{H}_{2} \mathrm{O}$}

$\mathrm{V}_{2} \mathrm{O}_{5} 2 \mathrm{~g}(10 \mathrm{mmol})$ dissolved in $100 \mathrm{~mL}$ of $0.5 \mathrm{M} \mathrm{CH}_{3} \mathrm{COOH} / \mathrm{CH}_{3} \mathrm{COONa}$ buffer solution $(\mathrm{pH}=4.8)$ with stirring. The turbid solution was heated and kept at $80{ }^{\circ} \mathrm{C}$ for $1 \mathrm{~h}$. Then the solution was filtered off and Potassium chloride $(7.0 \mathrm{~g})$ was added to the solution and the mixture was stirred for $15 \mathrm{~min}$. The orange single crystals suitable for crystallography were obtained from the solution after five days at room temperature. The crystal samples air-dried at room temperature.

\section{Single-crystal $x$-ray diffraction analysis}

An orange prismatic single crystal of $\mathrm{H}_{20} \mathrm{~K}_{4} \mathrm{Na}_{2} \mathrm{O}_{38} \mathrm{~V}_{10}$ with dimensions $0.31 \times 0.21 \times 0.12 \mathrm{~mm}^{3}$ was used for the $\mathrm{x}$-ray work. $\mathrm{H}_{20} \mathrm{~K}_{4} \mathrm{Na}_{2} \mathrm{O}_{38} \mathrm{~V}_{10}$ crystallizes in the triclinic system (space group $\mathrm{P}-1$ ) with $\mathrm{a}=8.5584(5) \AA, \mathrm{b}=10.3041(6) \AA, \mathrm{c}=10.9801(7) \AA$ and $\mathrm{Z}=1$. Intensity measurements were made at $100 \mathrm{~K}$ on a Bruker SMART $1000 \mathrm{CCD}$ single crystal diffractometer with graphitemonochromated Mo $\mathrm{K} \alpha$ radiation $(\lambda=0.71073 \AA)$. A total of 4799 independent reflections $(2 \theta \max =60.00$ and $\operatorname{Rint}=0.0217)$ were recorded, of which reflections were considered $[\mathrm{I}>2 \sigma(\mathrm{I})]$. The final cycle of refinement converged at $\mathrm{R}=0.0218$ and of $\mathrm{Rw}=0.0694[\mathrm{I}>2 \sigma(\mathrm{I})]$.

Crystallographic data and structure refinement parameters are listed in Table 1. The intensities were corrected for Lorentz-polarization effects, and the SADABS program ${ }^{10}$ was applied for absorption correction. The structure was refined with SHELXL-97 ${ }^{11}$ by full-matrix least-squares on F2. The weighting scheme was $\mathrm{w}=1 /\left[\sigma^{2}\left(\mathrm{~F}_{0}^{2}\right)+(0.0860 \mathrm{P})^{2}\right]$ where $\mathrm{P}=\left(\mathrm{F}_{0}{ }^{2}+2 \mathrm{~F}_{\mathrm{c}}{ }^{2}\right) / 3$. Atomic coordinates in Table 2 and Bond lengths $\mathrm{K}_{4} \mathrm{Na}_{2} \mathrm{~V}_{10} \mathrm{O}_{28} \cdot 20 \mathrm{H}_{2} \mathrm{O}$ are given in Table 3.

Table 1. Crystal data and structure refinement for $\mathrm{K}_{4} \mathrm{Na}_{2} \mathrm{~V}_{10} \mathrm{O}_{28} \cdot 20 \mathrm{H}_{2} \mathrm{O}$

\begin{tabular}{|c|c|}
\hline Empirical formula & $\mathrm{H}_{20} \mathrm{~K}_{4} \mathrm{Na}_{2} \mathrm{O}_{38} \mathrm{~V}_{10}$ \\
\hline Formula weight & 1339.94 \\
\hline Temperature(K) & $100(2)$ \\
\hline Wavelength $(\AA)$ & 0.71073 \\
\hline Crystal system & Triclinic \\
\hline Space group & P -1 \\
\hline \multicolumn{2}{|l|}{ Unit cell dimensions } \\
\hline $\mathrm{a}(\AA)$ & $8.5584(5)$ \\
\hline $\mathrm{b}(\AA)$ & $10.3041(6)$ \\
\hline$c\left(\AA^{\prime}\right)$ & 10.9801(7) \\
\hline$\alpha\left(^{\circ}\right)$ & $69.4520(10)$ \\
\hline$\beta\left(^{\circ}\right)$ & $87.4240(10)$ \\
\hline$\gamma\left({ }^{\circ}\right)$ & $66.0980(10)$ \\
\hline Volume $\left(\AA^{3}\right)$ & $823.57(9)$ \\
\hline $\mathrm{Z}$ & 1 \\
\hline Dcalc $\mathrm{Mg} / \mathrm{m}^{3}$ & 2.702 \\
\hline $\mathrm{F}(000)$ & 652 \\
\hline$\theta$ range for data collection $\left(^{\circ}\right)$ & $1.99-30.00$ \\
\hline Crystal size $\left(\mathrm{mm}^{3}\right)$ & $0.31 \times 0.21 \times 0.12$ \\
\hline Reflections collected & 14214 \\
\hline Independent reflections & $4799[\mathrm{R}(\mathrm{int})=0.0217]$ \\
\hline $\begin{array}{l}\text { Completeness to } \theta=30.00^{\circ}, \% \\
0.6838,0.4203\end{array}$ & 99.7 \\
\hline Refinement method & Full-matrix least-squares on F2 \\
\hline Data / restraints / parameters & $4799 / 0 / 244$ \\
\hline Goodness-of-fit on $\mathrm{F}^{2}$ & 1.002 \\
\hline Final $\mathrm{R}$ indices $[\mathrm{I}>2 \sigma(\mathrm{I})]$ & $\mathrm{R} 1=0.0218, \mathrm{wR} 2=0.0694$ \\
\hline $\mathrm{R}$ indices (all data) & $\mathrm{R} 1=0.0269, \mathrm{wR} 2=0.0726$ \\
\hline Largest diff. peak and hole $\left(\mathrm{e} . \AA^{-3}\right)$ & 1.048 and -0.618 \\
\hline
\end{tabular}


Table 2. Atomic coordinates $\left(\times 10^{4}\right)$ and equivalent isotropic displacement parameters $\left(\AA^{2} \times 10^{3}\right)$ for $\mathrm{K}_{4} \mathrm{Na}_{2} \mathrm{~V}_{10} \mathrm{O}_{28} \cdot 20 \mathrm{H}_{2} \mathrm{O} \mathrm{U}(\mathrm{eq})$ is defined as one third of the trace of the orthogonalized $\mathrm{U}^{\mathrm{ij}}$ tensor

\begin{tabular}{cccc}
\hline $\mathrm{X}$ & $\mathrm{Y}$ & $\mathrm{Z}$ & $\mathrm{U}(\mathrm{eq})$ \\
\hline $\mathrm{V}(1)$ & $6676(1)$ & $2905(1)$ & $2758(1)$ \\
$\mathrm{V}(2)$ & $8101(1)$ & $5(1)$ & $5197(1)$ \\
$\mathrm{V}(3)$ & $8766(1)$ & $2874(1)$ & $4995(1)$ \\
$\mathrm{V}(4)$ & $9691(1)$ & $38(1)$ & $2553(1)$ \\
$\mathrm{V}(5)$ & $10255(1)$ & $2916(1)$ & $2330(1)$ \\
$\mathrm{K}(1)$ & $7508(1)$ & $3072(1)$ & $-702(1)$ \\
$\mathrm{K}(2)$ & $6841(1)$ & $-2849(1)$ & $4871(1)$ \\
$\mathrm{Na}(1)$ & $4295(1)$ & $1659(1)$ & $-1282(1)$ \\
$\mathrm{O}(1)$ & $4726(2)$ & $3921(1)$ & $2075(1)$ \\
$\mathrm{O}(2)$ & $7458(2)$ & $1370(1)$ & $2021(1)$ \\
$\mathrm{O}(3)$ & $7930(2)$ & $3835(1)$ & $1733(1)$ \\
$\mathrm{O}(4)$ & $6680(2)$ & $3707(1)$ & $4030(1)$ \\
$\mathrm{O}(5)$ & $6222(2)$ & $1268(1)$ & $4273(1)$ \\
$\mathrm{O}(6)$ & $7644(2)$ & $-1315(1)$ & $6431(1)$ \\
$\mathrm{O}(7)$ & $8956(2)$ & $-1209(1)$ & $4139(1)$ \\
$\mathrm{O}(8)$ & $10034(2)$ & $-1022(1)$ & $1682(1)$ \\
$\mathrm{O}(9)$ & $8176(2)$ & $1196(1)$ & $6185(1)$ \\
$\mathrm{O}(10)$ & $9299(1)$ & $1250(1)$ & $3934(1)$ \\
$\mathrm{O}(11)$ & $10564(2)$ & $1392(1)$ & $1654(1)$ \\
$\mathrm{O}(12)$ & $8409(2)$ & $3908(1)$ & $5878(1)$ \\
$\mathrm{O}(13)$ & $9817(2)$ & $3712(1)$ & $3666(1)$ \\
$\mathrm{O}(14)$ & $11061(2)$ & $3961(1)$ & $1329(1)$ \\
$\mathrm{O}(1 \mathrm{~W})$ & $4231(2)$ & $3238(1)$ & $-203(1)$ \\
$\mathrm{O}(2 W)$ & $2936(2)$ & $122(1)$ & $139(1)$ \\
$\mathrm{O}(3 W)$ & $4713(2)$ & $182(2)$ & $-2545(1)$ \\
$\mathrm{O}(4 W)$ & $4606(2)$ & $-3115(2)$ & $2891(1)$ \\
$\mathrm{O}(5 W)$ & $8356(2)$ & $-3168(1)$ & $2592(1)$ \\
\hline
\end{tabular}

Table 3. Selected bond lengths $(\AA)$

\begin{tabular}{cccccc}
\hline $\mathrm{V}(2)-\mathrm{O}(5)$ & $1.6830(12)$ & $\mathrm{V}(4)-\mathrm{O}(11)$ & $1.8138(12)$ & $\mathrm{K}(1)-\mathrm{O}(2 \mathrm{~W}) \# 4$ & $3.3042(13)$ \\
$\mathrm{V}(2)-\mathrm{O}(6)$ & $1.7112(12)$ & $\mathrm{V}(4)-\mathrm{O}(9) \# 1$ & $1.9944(12)$ & $\mathrm{K}(2)-\mathrm{O}(5) \# 5$ & $2.7933(12)$ \\
$\mathrm{V}(2)-\mathrm{O}(7)$ & $1.9108(12)$ & $\mathrm{V}(4)-\mathrm{O}(7)$ & $2.0162(12)$ & $\mathrm{K}(2)-\mathrm{O}(5 \mathrm{~W})$ & $2.8274(14)$ \\
$\mathrm{V}(2)-\mathrm{O}(9)$ & $1.9219(12)$ & $\mathrm{V}(4)-\mathrm{O}(10)$ & $2.2165(11)$ & $\mathrm{K}(2)-\mathrm{O}(12) \# 6$ & $2.8456(13)$ \\
$\mathrm{V}(2)-\mathrm{O}(10)$ & $2.0760(12)$ & $\mathrm{V}(5)-\mathrm{O}(14)$ & $1.5955(13)$ & $\mathrm{K}(2)-\mathrm{O}(7)$ & $2.8585(12)$ \\
$\mathrm{V}(2)-\mathrm{O}(10) \# 1$ & $2.1281(12)$ & $\mathrm{V}(5)-\mathrm{O}(3)$ & $1.8544(13)$ & $\mathrm{K}(2)-\mathrm{O}(3 \mathrm{~W}) \# 4$ & $2.8743(14)$ \\
$\mathrm{V}(1)-\mathrm{O}(3)$ & $1.8184(12)$ & $\mathrm{V}(5)-\mathrm{O}(13)$ & $1.8744(12)$ & $\mathrm{K}(2)-\mathrm{O}(6)$ & $2.9651(12)$ \\
$\mathrm{V}(1)-\mathrm{O}(4)$ & $1.8563(12)$ & $\mathrm{V}(5)-\mathrm{O}(11)$ & $1.8837(12)$ & $\mathrm{K}(2)-\mathrm{O}(13) \# 1$ & $2.9835(13)$ \\
$\mathrm{V}(1)-\mathrm{O}(2)$ & $1.8968(12)$ & $\mathrm{V}(5)-\mathrm{O}(6) \# 1$ & $2.0118(12)$ & $\mathrm{K}(2)-\mathrm{O}(4 \mathrm{~W})$ & $3.1113(16)$ \\
$\mathrm{V}(1)-\mathrm{O}(5)$ & $2.0648(12)$ & $\mathrm{V}(5)-\mathrm{O}(10)$ & $2.3670(12)$ & $\mathrm{K}(2)-\mathrm{H}(9)$ & 3.064 \\
$\mathrm{~V}(1)-\mathrm{O}(10)$ & $2.2862(12)$ & $\mathrm{K}(1)-\mathrm{O}(1) \# 2$ & $2.7761(13)$ & $\mathrm{K}(2)-\mathrm{H}(10)$ & 3.0406 \\
$\mathrm{~V}(3)-\mathrm{O}(12)$ & $1.6137(12)$ & $\mathrm{K}(1)-\mathrm{O}(1 \mathrm{~W})$ & $2.7809(15)$ & $\mathrm{Na}(1)-\mathrm{O}(1 \mathrm{~W})$ & $2.3085(14)$ \\
$\mathrm{V}(3)-\mathrm{O}(13)$ & $1.8195(12)$ & $\mathrm{K}(1)-\mathrm{O}(8) \# 3$ & $2.7997(12)$ & $\mathrm{Na}(1)-\mathrm{O}(3 \mathrm{~W})$ & $2.3160(14)$ \\
$\mathrm{V}(3)-\mathrm{O}(4)$ & $1.8268(12)$ & $\mathrm{K}(1)-\mathrm{O}(2)$ & $2.8952(12)$ & $\mathrm{Na}(1)-\mathrm{O}(4 \mathrm{~W}) \# 4$ & $2.3217(15)$ \\
$\mathrm{V}(3)-\mathrm{O}(7) \# 1$ & $1.9895(12)$ & $\mathrm{K}(1)-\mathrm{O}(4 \mathrm{~W}) \# 4$ & $3.0499(16)$ & $\mathrm{Na}(1)-\mathrm{O}(5 \mathrm{~W}) \# 4$ & $2.3447(15)$ \\
$\mathrm{V}(3)-\mathrm{O}(9)$ & $2.0039(12)$ & $\mathrm{K}(1)-\mathrm{O}(3)$ & $3.1127(13)$ & $\mathrm{Na}(1)-\mathrm{O}(2 \mathrm{~W}) \# 4$ & $2.3839(14)$ \\
$\mathrm{V}(3)-\mathrm{O}(10)$ & $2.2515(11)$ & $\mathrm{K}(1)-\mathrm{O}(11)$ & $3.2132(13)$ & $\mathrm{Na}(1)-\mathrm{O}(2 \mathrm{~W})$ & $2.4271(14)$ \\
$\mathrm{V}(4)-\mathrm{O}(8)$ & $1.6256(12)$ & $\mathrm{V}(2)-\mathrm{V}(5) \# 1$ & $3.0961(4)$ & $\mathrm{Na}(1)-\mathrm{Na}(1) \# 4$ & $3.3576(14)$ \\
$\mathrm{V}(4)-\mathrm{O}(2)$ & $1.8132(12)$ & $\mathrm{V}(1)-\mathrm{O}(1)$ & $1.6094(13)$ & & \\
\hline$\# 1-x+2,-y,-z+1$ & $\# 2-x+1,-y+1,-\mathrm{z}(13-x+2,-y,-z ; \# 4-x+1,-y,-\mathrm{z}$ & $\# 5-x+1,-y,-z+1 ; \# 6 x, y-1, z$
\end{tabular}




\section{IR and Raman spectroscopy}

The FT- IR spectrum shows characteristic vibrational features similar to other polyoxovanadates reported (Figure 1). The presence of well-differentiated $\mathrm{V}-\mathrm{O}$ linkages in the crystal structures of compounds indicates the possibility of a large number of internal vibrations. The FT-IR spectra showing one strong band at $\sim 949 \mathrm{~cm}^{-1}$ that can be assigned to the stretching of the terminal $\mathrm{V}-\mathrm{O}$ bonds. The bridging antisymmetric vibrations of $\mathrm{V}-\mathrm{O}-\mathrm{V}$ possibly correspond to the bands at $\sim 746,804$ and $\sim 843 \mathrm{~cm}^{-1}$, while the symmetric ones are probably at 521 and $596 \mathrm{~cm}^{-1}$. IR and Raman spectra of $\mathrm{K}_{4} \mathrm{Na}_{2} \mathrm{~V}_{10} \mathrm{O}_{28} \cdot 20 \mathrm{H}_{2} \mathrm{O}$ (Figure 1) are not similar; therefore it confirms that this compound has a centrosymmetric structure.

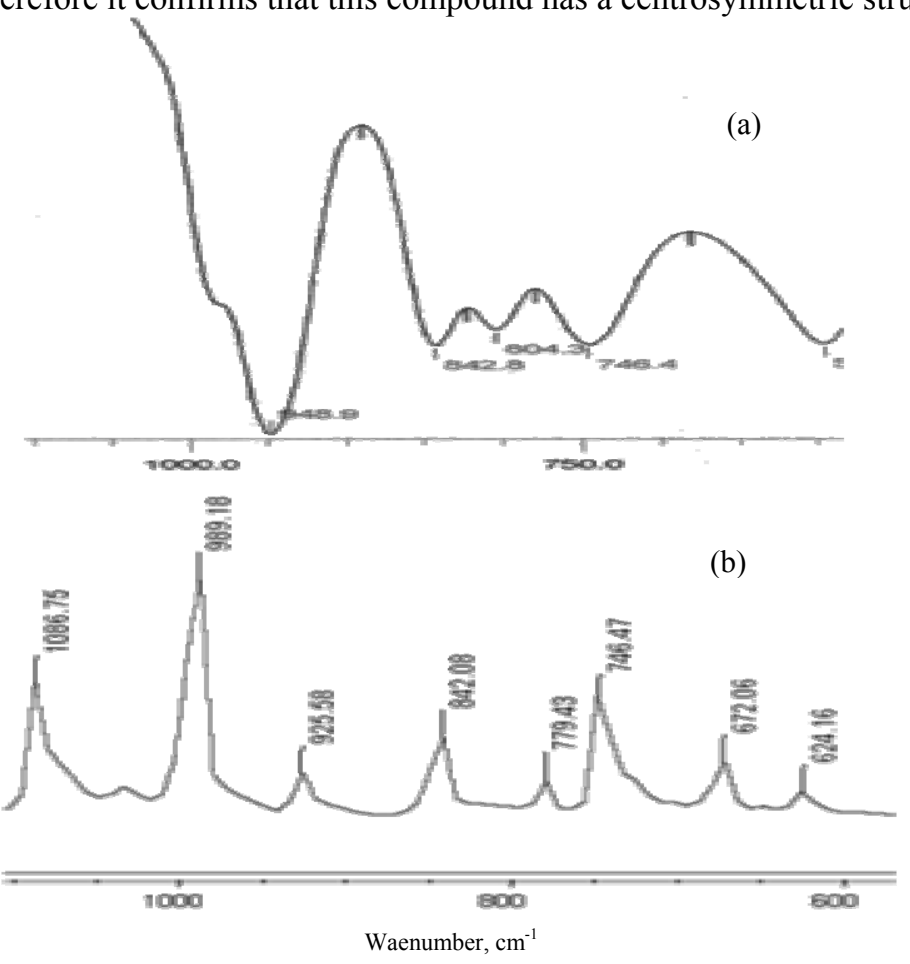

\section{Results and Discussion}

Figure 1. (a) IR and (b) Raman spectrums

\section{The structural unit}

The $\left[\mathrm{V}_{10} \mathrm{O}_{28}\right]^{6-}$ decavanadate structural unit is the fundamental building block of the hummerite atomic arrangement. Figure 1 shows the structural unit and Figure 2 illustrates the linkage of adjacent structural units by the interstitial contents. The structural unit is centrosymmetric and formed of ten edge-sharing octahedra; there is a similar fundamental buildings block in pascoite, $\mathrm{Ca}_{3} \mathrm{~V}_{10} \mathrm{O}_{28}{ }^{\bullet}\left(\mathrm{H}_{2} \mathrm{O}\right)_{17}{ }^{12}$. In the structural unit, each of the octahedra contains a single vanadyl bond with distance less than $1.683 \AA$. In addition to bonding to the vanadium atoms of the structural unit, the oxygen atoms of the structural unit bond to the potassium atom of the interstitial complex and to the hydrogen atoms of the $\left(\mathrm{H}_{2} \mathrm{O}\right)$ groups of the interstitial complex. Oxygen $\mathrm{O} 3$ of the structural unit is of particular interest in the structural unit. As depicted in Figure 1, $\mathrm{O} 3$ bonds to six vanadium atoms, an unusual coordination for oxygen, particularly when bonded to such a highly charged cation 
as pentavalent vanadium. The vanadium-oxygen bonds to $\mathrm{O} 3$ are the longest in each vanadium polyhedron, and thus the bond-valence is the lowest among the bonds. The bondvalence sum of 1.98 valence units, vu, for $\mathrm{O} 3$ demonstrates that despite the unusually large coordination number for oxygen, the atom arrangement maintains the valence-matching principle. The crystal structure of this compound was already reported by others ${ }^{13}$, but we carried out crystallography on this compound in low temperature $(100 \mathrm{~K})$ and synthesis method is different and the quality of our x-ray results is significantly better (e.g. $\mathrm{R}=0.0269$ ).

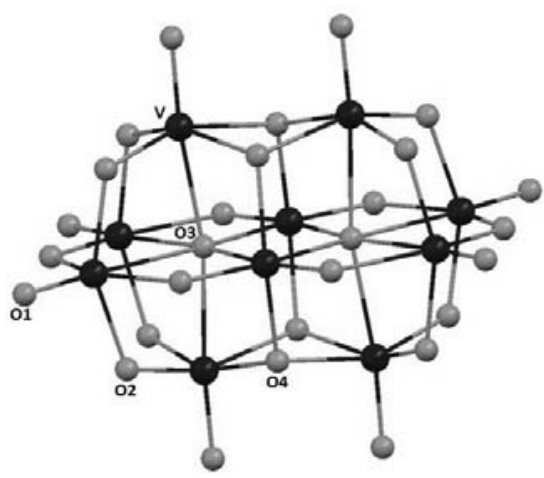

The interstitial complex

Figure 2. $\mathrm{V}_{10} \mathrm{O}_{28}{ }^{6-}$ structural unit

The symmetry-equivalent structural units in hummerite are connected by the interstitial complex ${ }^{14}$. The interstitial complex in hummerite is $\left[\mathrm{K}_{4} \mathrm{Na}_{2}\left(\mathrm{H}_{2} \mathrm{O}\right)_{20}\right]^{6+}$. All oxygen atoms in the interstitial complex occur as $\left(\mathrm{H}_{2} \mathrm{O}\right)$ groups, in contrast to the structural unit, which is devoid of hydrogen atoms. The $\mathrm{Na}$ atom bonds to six $\left(\mathrm{H}_{2} \mathrm{O}\right)$ groups in a regular octahedral arrangement (c.f.Table 3) and does not bond directly to the structural unit. Potassium bonds to eight atoms of oxygen, five of them belong to the decavanadate structural unit and three of which are $\left(\mathrm{H}_{2} \mathrm{O}\right)$ groups of the interstitial complex. In addition to the bonding between five oxygen atoms of the structural unit and the interstitial potassium, there is an extensive network of hydrogen bonds linking the two structural components. Figure 3 depicts all hydrogen bonds with distance $\leq 2.013 \AA$.

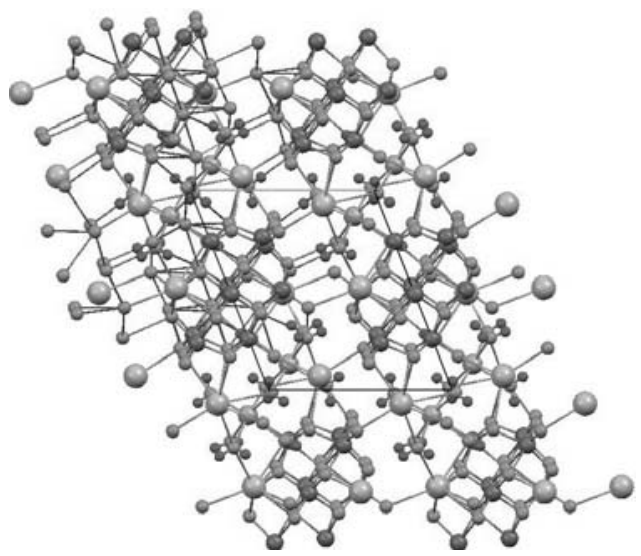

Figure 3. Unit cell of $\mathrm{K}_{4} \mathrm{Na}_{2} \mathrm{~V}_{10} \mathrm{O}_{28} \cdot 20 \mathrm{H}_{2} \mathrm{O}$ 


\section{Appendix A. supplementary data}

Crystallographic data (CIF file) for the structural analysis have been deposite with the Fachinformationszentium Karlsruhe (FIZ), CSD-number 380351. These data can be obtaine free of charge via E-mail: crysdata@FIZ-Karsruhe.de. Tel: +49 7247 808-205; fax: +49 $7247808-666$.

\section{References}

1. Pope M T and Müller A, Polyoxometalates: From Platonic Solids to Anti-Retroviral Activity, Kluwer, Dordrecht, 1994.

2. $\quad$ Pope M T, Hetero and isopolymetalate, Springer, Berlin 1983.

3. Stankiewicz P J, Tracey A S and Crans D C, Vanadium and its Role in Life, Metal Ions in Biological Systems. Sigel H and Sigel A, Eds., 21, Marcel Dekker, New York, 1995.

4. Alexandrova A, Kirkova M and Russanov E, Gen Pharm., 1998, 31(3), 489-493.

5. Zavalij P Y and Whittingham M S, Acta Crystallogr B, 1999, 55, 627-663.

6. Blasco T and López Nieto J M, Appl Catal., 1997, 157, 117.

7. Kung H H, Adv Catal., 1995, 133, 219.

8. Albonetti S, Cavani F and Trifiro F, Catal Rev Sci Eng.,1996, 38, 413.

9. Stankiewick P J, Tracey A S, Crans D C, Vanadium and its Role in Life, Metal Ions in Biological Systems. H. Sigel, A. Sigel, Eds. 21, Marcel Dekker, New York, 1995.

10. Sheldrick G M, SADABS v. 2.01, Bruker/Siemens Area Detector Absorption Correction Program, Bruker AXS, Madison, WI, USA, 1998.

11. Sheldrick G M, SHELEX v. 5.10, Structure Determination software Suit, Bruker AXS, Madison, WI, USA, 1998.

12. Swallow A G, Ahmed F R and Barnes W H, Acta Crystallogr., 1966, 21, 397-405.

13. Lee U, Jang S Jand Joo H C, Acta Cryst., 2003, 59, 345-347

14. Schindler M and Baur W H, Can Mineral., 2000a, 38, 1443-1456. 


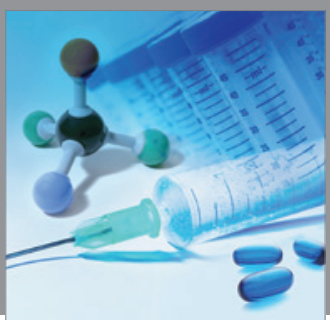

International Journal of

Medicinal Chemistry

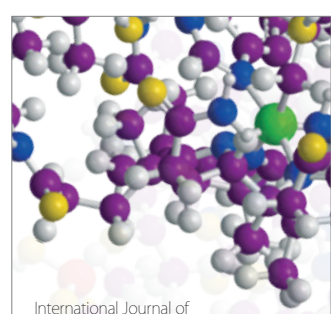

Carbohydrate Chemistry

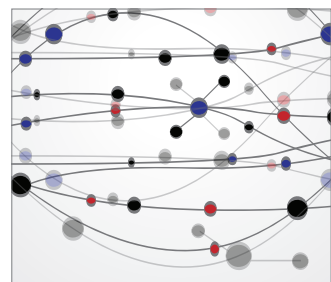

The Scientific World Journal
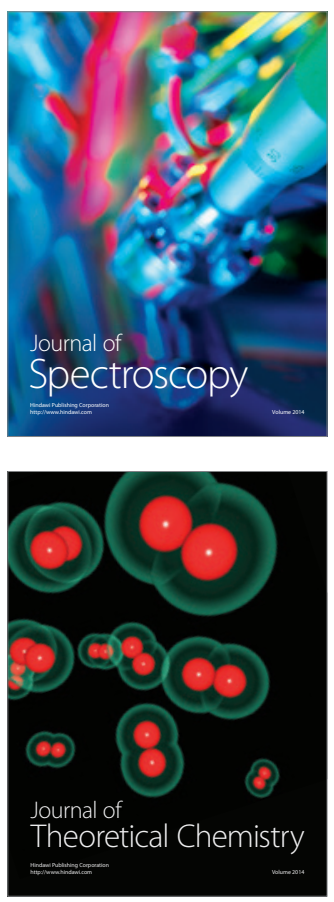
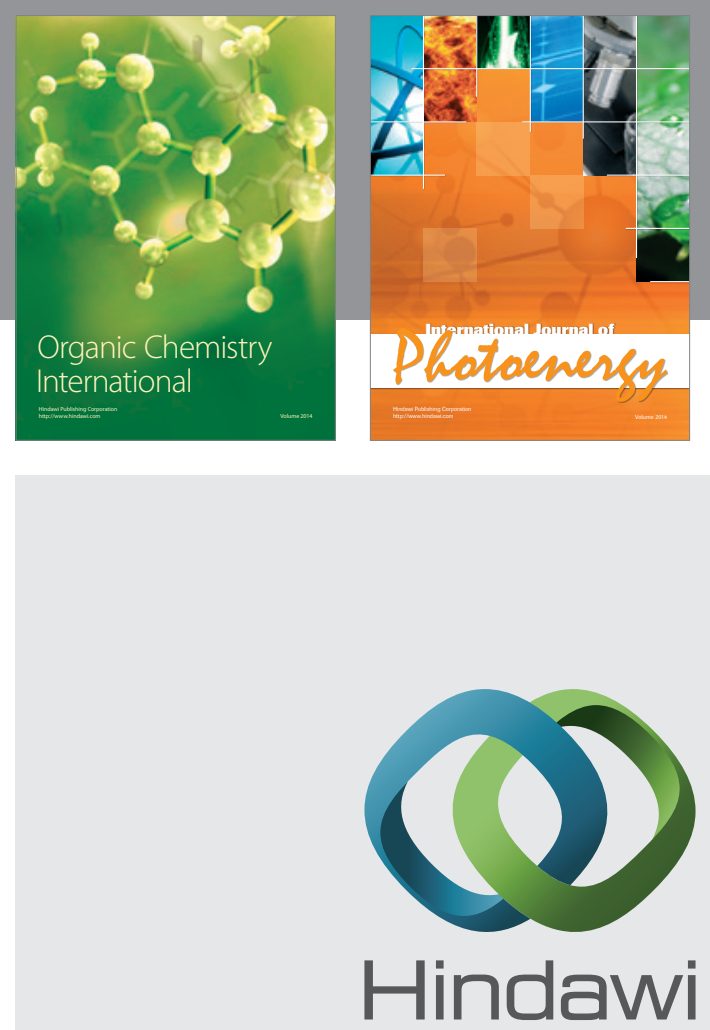

Submit your manuscripts at

http://www.hindawi.com
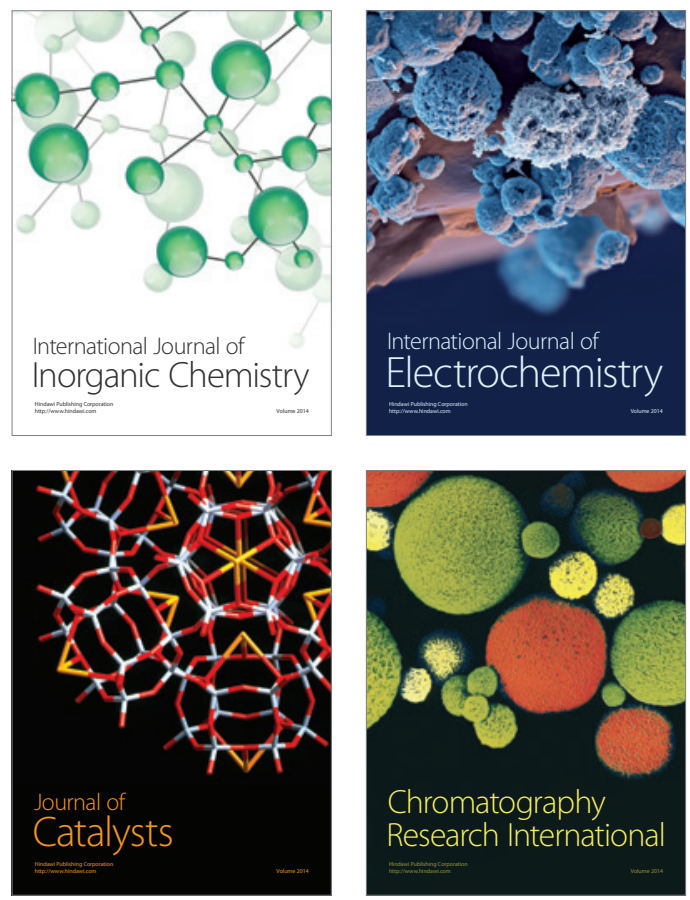
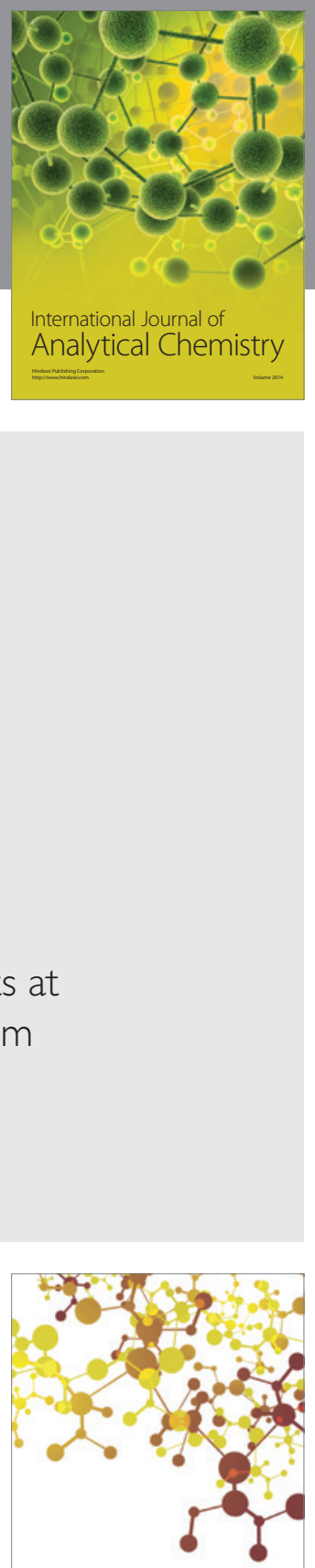

Journal of

Applied Chemistry
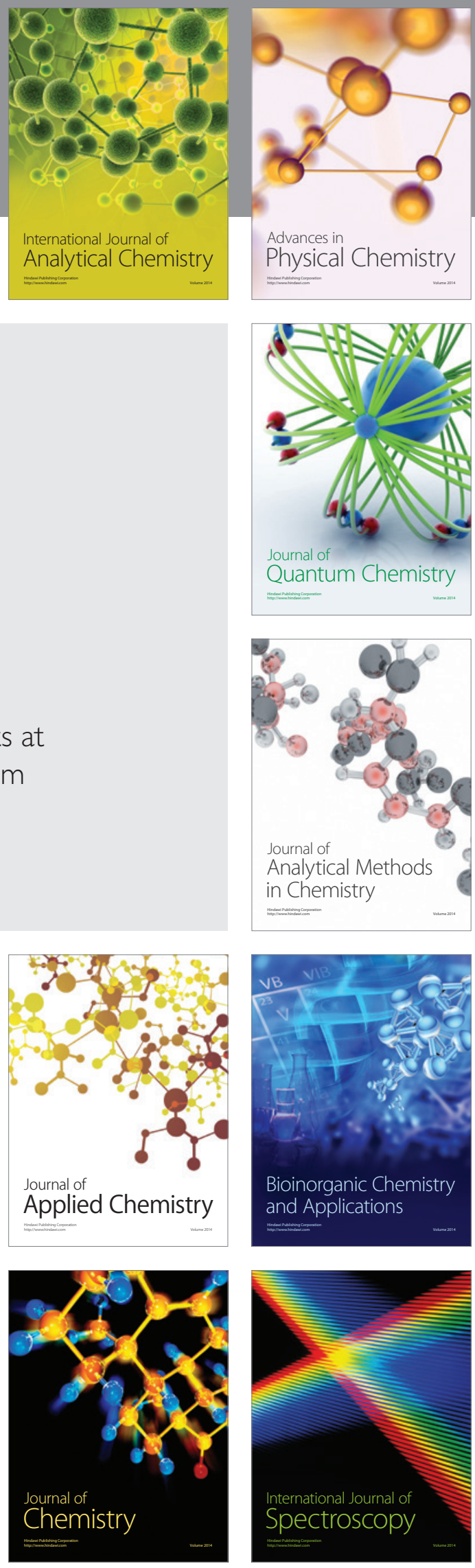